\title{
Live tracking of saline for betterment of patient
}

\author{
Sayli Zende, Avinash Devare, Tanvi Kulkarni, Shubhada Yadav, Ajay Biradar \\ Department of Computer Engineering, Trinity Academy of Engineering, Pune, India
}

\begin{tabular}{|c|c|}
\hline Article Info & ABSTRACT \\
\hline Article history: & \multirow{10}{*}{$\begin{array}{l}\text { In hospitals, Saline is fed to patients to treat dehydration and use of saline } \\
\text { improves their health. In current health care measures, whenever a saline is } \\
\text { fed to any patient, the patient must be continuously monitored by nurse, } \\
\text { doctor or caretaker. So basically, in all the hospitals nurse or caretaker is } \\
\text { responsible for monitoring of saline. Due to the avoidance of nurses towards } \\
\text { the saline level monitoring or lack of knowledge it can harm to the patients } \\
\text { health. Therefore, to stop the patient from obtaining injured and shield their } \\
\text { lives throughout saline feeding amount, the saline level observance system } \\
\text { are developed. The planned system is made Internet web of Things (IoT) } \\
\text { platform. The planned system includes of devices which can act as tier sensor } \\
\text { for observance the crucial level of the saline within the saline bottle. } \\
\text { Whenever the amount of the saline reaches to the predefined crucial level, } \\
\text { then the nurses, caretaker, doctors are alerted through the alarm associate in } \\
\text { Nursing an alert message are sent through the utilization of web to the } \\
\text { involved nurses and doctors that there's a requirement for replacement of the } \\
\text { saline bottle. This planned system may be utilized efficiently in homes as } \\
\text { well as hospitals. }\end{array}$} \\
\hline Received Dec 17, 2019 & \\
\hline Revised Jan 12, 2020 & \\
\hline Accepted Mar 19, 2020 & \\
\hline Keywords: & \\
\hline Arduino micro-controller & \\
\hline Internet of things & \\
\hline Live tracking & \\
\hline Load cell sensors & \\
\hline Saline & \\
\hline
\end{tabular}

This is an open access article under the CC BY-SA license.

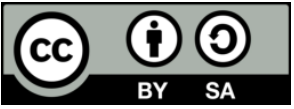

Corresponding Author:

Sayli Anand Zende,

Department of Computer Engineering,

Trinity Academy of Engineering,

Bopdev Ghat Road Kondhwa Saswad Road, Yewalewadi, Pune, Maharashtra 411001, India.

Email: saylizende15@gmail.com

\section{INTRODUCTION}

The Internet of Things (IoT) is a system which consists of interrelated devices. Which is used to transfer the data over the network without having interaction between humans or in between human and computers? The Internet of Things has evolved due to the occurrence of multiple technologies, real-time analytic, machine learning, commodity sensors, and embedded systems. IoT devices can be used in remote health monitoring and notification systems. IoT devices can be used to detect blood pressure, heartbeat, and many more parameters regarding to the health. Some hospitals implementing "smart beds" so that can detect when they are occupied and when patient needs to get up. The patient's needs to be continuously monitored by nurse, doctor or any caretaker at the time of saline fed to patient. Many times due to the connivance, busy schedule, number of patients, the nurse may forget to change the saline bottle as soon as it is totally consumed. When saline bottle finishes, blood passes reverse back to the saline bottle because of the difference between in pressure of blood and pressure present into the saline empty bottle. This may cause back flow of blood to saline bottle from their vein. These results in the reduction of hemoglobin level of patients and may also lead to shortage of red blood cells (RBCs) in the patient's blood causing tiredness. Therefore, there is a need of developing a saline level monitoring system which will reduce the patient's dependency on the nurses or caretakers to some extent. 


\section{LITERATURE SURVEY}

In [1], proposed a research paper "Smart saline level indicatorcum controller," The saline is suspended in a small box like arrangement which has a spring system as shown in Figure 1. There is one spring which can be act as a weight sensor i.e. the spring differentiate the filled bottle and empty bottle as per the weight of that bottle. The operation is two-fold. First when the saline drops downs a liquid to a certain low level then an alarm is placed closed to the nurse chamber to alert the nurse that the saline fed to the patient is over. Moreover in addition to the alarm a set of red light and green light are also provided where red indicates that level of saline is low while green indicates a safe level of fluid inside the bottle. The mechanical part is of a spring which acts as a weight sensor and synchronized with electronic switch. The electronic circuit contains ICs like op-amp, voltage regulator and components like transistors, resistors.

In [2], proposed a research paper "Smart hospitals using internet of things (IoT)." In this system using IoT, one can regulate electrical appliances and continuously supervised patients from distant position. The internet of things technology is a revolutionary change maker for the health care industry. Nowadays, health care industry is investing its resources in IoT to promote innovation and improvement intheir procedures Various hospitals use various ER services, and are already using smart health care solutions to achieve precision in results, for better prediction and for preemptive management plans.

In [3], proposed a research paper "Saline infusion level detection and heart rate monitoring system." In order to monitor the level of liquid in the drips bottle, a level sensor is used. Whenever the saline level goes below the nominal rate, it is notified using an alarm and this information is passed to the hospital attendant, using GSM. Using a capacitive probe, the infusion rate is measured and the number of drops passing through the drip chamber per minute, i.e. drip rate is displayed.

In [4], proposed research paper "An IoT based patient monitoring system using raspberry Pi," In this paper they had work on a patient body temperature,respiration rate, heart beat, body temperature, respiration rate and body movement. They used the Raspberry Pi board to monitor the system. With the help of sensors thy calculate the patient health related activities by using IoT technology. The purpose of this system is to reduce the cost and reduce the time.

In [5], proposed a research paper "Health care monitoring system in internet of things (IoT) by using RFID." They had proposed a complete automatic monitoring cycle and effective health care system using IoT and RFID tags.This system to get the accurate or proper evaluation result,supervise the patient health status and increase the IoT power. The system calculate the patient blood pressure, body temperature,motion,glucose rate and send the information via SMS to the mobile application which is access by patient and their relatives and doctors.

In [6], proposed a research paper "IoT based saline level monitoring system." They had proposed system comprises of sensors which will act as a level sensor form on it controlling the critical level of the saline in the saline bottle. Whenever the level of the saline reaches to the predefined critical level, then the nurses, caretaker, doctors will be alerted through the buzzer and an alert message will be sent through the use of internet to the concerned nurses and doctors that there is a need for replacement of the saline bottle. This proposed system can be utilized efficiently in homes as well as hospitals.

In [7], proposed a research paper "Smart health monitoring system with IoT," They had work on patient health.They invented a wearable devices which is monitor the patient health activities and send the information through API technology.In this system they used a data mining technique with rule induction algorithm to find association rules for the purpose of system. They design a web and mobile application to display the result. Comparison of methods used in the literature survey as show in Table 1. 
Table 1. Comparison of methods used in the literature survey

\begin{tabular}{|c|c|c|c|}
\hline Reference & Methodology & Advantage & Disadvantage \\
\hline [4] & $\begin{array}{l}\text { Raspberry Pi board } \\
\text { based health care }\end{array}$ & $\begin{array}{l}\text { Small size device, affordable cost, } \\
\text { and high accuracy. }\end{array}$ & $\begin{array}{l}\text { many sensor are used to give intimation to } \\
\text { change the intravenous set at the last moment, } \\
\text { this may leads to serious health problems }\end{array}$ \\
\hline$[8]$ & $\begin{array}{l}\text { Micro-controller based } \\
\text { patient monitoring unit. }\end{array}$ & $\begin{array}{l}\text { Everything is being digitized, in } \\
\text { order to save time and to be precise. }\end{array}$ & $\begin{array}{l}\text { It uses manual drips meter which may creates } \\
\text { the formation of air bubbles in the intravenous } \\
\text { solution before entering the patient's body. }\end{array}$ \\
\hline [3] & $\begin{array}{l}\text { Infusion monitoring } \\
\text { devices using an IR } \\
\text { sensor. }\end{array}$ & $\begin{array}{l}\text { Cost effective, reliable, comfortable, } \\
\text { convenient, effortless and automatic } \\
\text { saline flow monitoring and control } \\
\text { system. }\end{array}$ & $\begin{array}{l}\text { Data may not be accurate due to the } \\
\text { interference by the Wi-Fi signals. }\end{array}$ \\
\hline$[5]$ & $\begin{array}{l}\text { RFID tags ,mobile } \\
\text { application }\end{array}$ & $\begin{array}{l}\text { Cost-effectiveness without } \\
\text { compromising with performance. }\end{array}$ & $\begin{array}{l}\text { This device aims to bring about a revolution in } \\
\text { the common medical sector which is sadly very } \\
\text { primitive and risky. }\end{array}$ \\
\hline [9] & $\begin{array}{l}\text { RF zigBee module ,flow } \\
\text { rate sensor and micro- } \\
\text { controller. }\end{array}$ & $\begin{array}{l}\text { Provides flexibility, saves lot of } \\
\text { time. }\end{array}$ & Needs improvement of accuracy.Higher cost. \\
\hline$[10]$ & $\begin{array}{l}\text { Remote health } \\
\text { monitoring devices. }\end{array}$ & $\begin{array}{l}\text { Reduces the power consumption and } \\
\text { decreases the cost of messages. }\end{array}$ & $\begin{array}{l}\text { If chip is transmitting and any data is input to } \\
\text { transmit, it will be kept in buffer for next } \\
\text { transmission cycle. Because it uses the half } \\
\text { duplex mode }\end{array}$ \\
\hline [6] & IOT with smart devices & Reduces manual efforts & It supports shorter range and lower data rate \\
\hline
\end{tabular}

\section{PROPOSED SYSTEM}

Due to more number of patient's, negligence, lack of knowledge towards how much saline is consumed by any patient, the traditional methods are used. Initially, traditional system uses IR sensors for monitoring saline level. But the consequences are often fatal. After the saline finishes, blood comes back to the saline bottle due to the air pressure in the empty bottle. So, the health monitoring systems have being developed with less human interactions which can be useful in rural as well as in urban areas along with low cost. The proposed system is used to solve the above problems effectively. This system makes the use of load cell to check the weight of saline. And EEPROM is used to store the saline threshold value for critical situations. As saline bottle finishes it informs to the nurse via mobile application by generating alarm and displays message. By this means the nurse can monitor the saline even if she is not available near that saline.

System architecture diagram is used to show the relationship between different components. Usually system architecture diagrams are created for those systems which include hardware and software and these can be used to represent in the interaction between them. Following figure shows the architecture of the system.

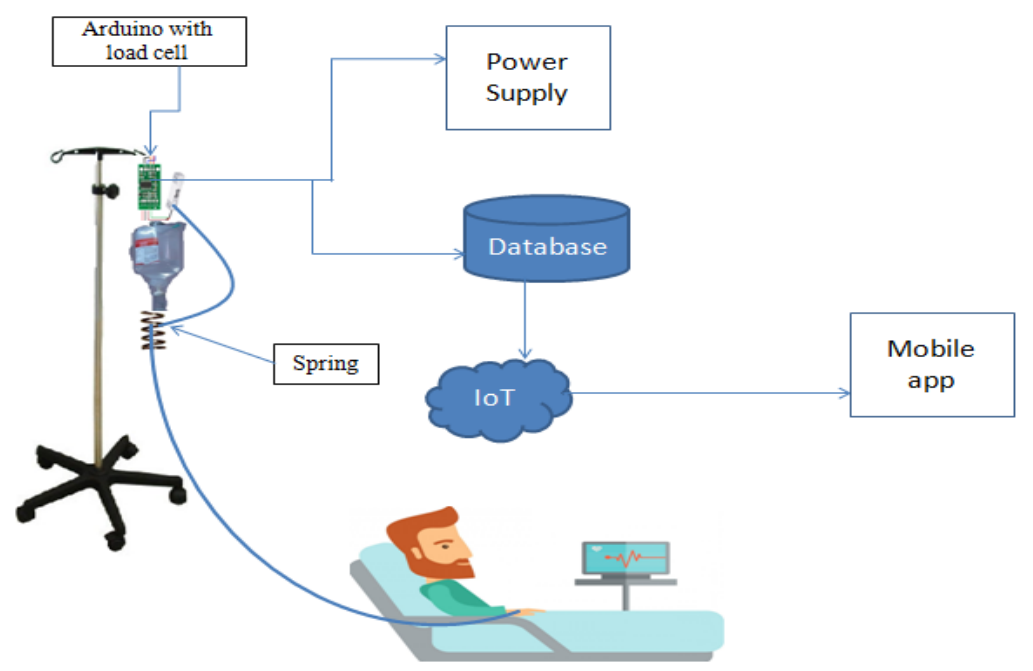

Figure 1. Architecture of proposed system

There is one form which is fill up by patient where is all information about their health is taken. Then that data is stored into database for future use. Then by using that data doctor creates report of that 
patient and do proper analysis of that report. According to that report doctor decides whether patient requires saline or not. If patient requires saline then saline is feed to that patient. When the saline level reaches to critical level at that time this system stops the flow of that saline. It checks the saline is empty or not, if it is empty then it generates alarm. If saline is not empty then it continuous the flow of saline. Finally, it displays the result.

\section{CONCLUSION}

The entire proposed system is automated, so it requires less human efforts and interactions. If saline finishes and still it is attached to the patient's body then it may harm to the patient. So, the proposed system saves the life of the patient's. It is used in urban as well as in rural areas with less cost. There will be advantage at night as there will be less number of nurses to take care of patients every time and also to check the saline level continuously. This system generates alarm after saline gets finished and informs nurse through mobile application.

\section{ACKNOWLEDGEMENTS}

In our endeavour to achieve the success in completing our project "Live tracking of saline for betterment of patient" in the Fourth Year Computer Engineering. We take this opportunity to express our deep sense of gratefulness to our guide Prof. Avinash. S. Devare for his valuable guidance and kind cooperation throughout the period of work. We express our thankfulness to all teachers and staff of computer department for timely help in project preparation. Finally, special thanks to our friends, family members and all others who have helped us directly or indirectly for successful completion of this work.

\section{REFERENCES}

[1] M. Kumar, S. Kumar Mallick, R. Sabat, "Smart saline level indicatorcum controller," International Journal of Application or Innovation in Engineering \& Management (IJAIEM), vol. 4, no. 3, pp. 299-301, 2015.

[2] P. Kanase, S. Gaikwad "Smart hospitals using internet of things (IoT)," International Research Journal of Engineering and Technology (IRJET), vol. 3, no. 03, 2016.

[3] P. Pearline Sheeba, N. Anushree, L. Aishwarya "Saline infusion level detection and heart rate monitoring system," International Journal for Research in Applied Science \& Engineering Technology, vol. 4, pp. 637-641, 2016.

[4] R. Kumar, M. Pallikonda Rajasekaran, "An IoT based patient monitoring system using raspberry Pi," 2016 International Conference on Computing Technologies and Intelligent Data Engineering (ICCTIDE'16), 2016.

[5] Sarfraz Khan "Health care monitoring System In Internet of Things (IoT) by using RFID," 2017 6th International Conference on Industrial Technology and Management (ICITM), 2017.

[6] Khushboo Vaishnav,Nargees Bano Haidarali ,Neha Swamy "IoT based saline level monitoring system," International Journal of Innovations \& Advancement in Computer Science, vol. 6, no. 10, pp. 65-69, 2017.

[7] Siriwan kajornkasirat, Napat chanapai and Benjawan Hnusunwan "Smart health monitoring syatem with IoT," 2018 IEEE Symposium on Computer Applications \& Industrial Electronics (ISCAIE), pp. 206-211, 2018.

[8] R. Vasuki, Dennis and Hem Priya Chander "Designing a portable monitoring device to measure the drips rate," Middle East J. Sci. Res, vol. 1, no. 1, pp. 29-35, 2011.

[9] I. S. Tawade, M.S. Pendse, H.P. Chaudhari "Design and development of saline flow rate monitoring system using flow sensor, microcontroller and RF ZigBee module," International Journal of Engineering Research And General Science, vol. 3, no. 3, pp. 472-478, 2015.

[10] R. Aravind, Syed Musthak Ahmed "Design of family health care monitoring system using wireless communication technology" International Journal of Advanced Research in Computer and Communication Engineering, vol. 2, no. 9 , pp. 3666-3671, 2013.

\section{BIOGRAPHIES OF AUTHORS}

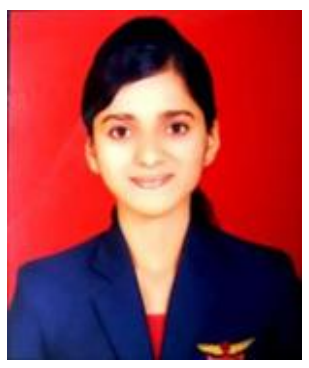

Sayli Zende pursuing Bachelor of Engineering. Degree in Computer Engineering from Savitribai Phule Pune University in 2020. Her research focus upon IoT and Cloud Security. And also, research focus in Software Defined Networking (SDN) support for Cloud and IoT. She is a student of Trinity Academy of Engineering, Pune. 


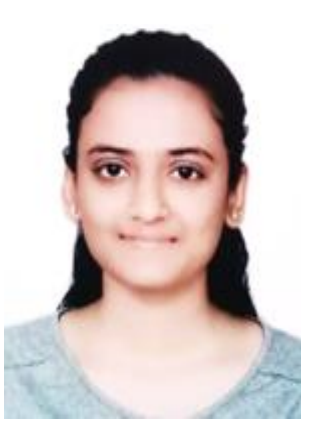

Tanvi Kulkarni pursuing Bachelor of Engineering. Degree in Computer Engineering from Savitribai Phule Pune University in 2020. Her research focus upon IoT based applications to automatically monitor the level of saline. And also, research focus in Data and Knowledge Management. She is a student of Trinity Academy of Engineering, Pune.

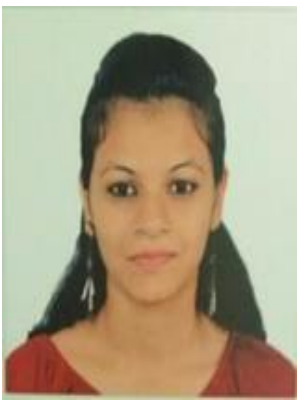

Shubhada Yadav pursuing Bachelor of Engineering. Degree in Computer Engineering from Savitribai Phule Pune University in 2020. Her research focus upon Tools and Technologies for IoT services. And also, focus in Smart Cloud and IoT. She is a student of Trinity Academy of Engineering, Pune.

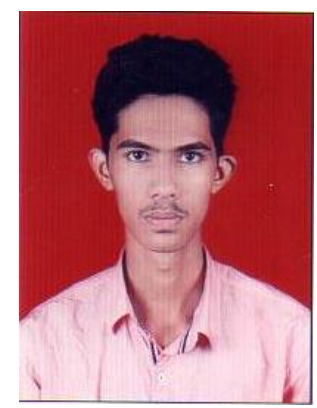

Ajay Biradar pursuing Bachelor of Engineering. Degree in Computer Engineering from Savitribai Phule Pune University in 2020. His research focus upon Embedded System Architecture. And also, focus in Smart Home and Cities. He is a student of Trinity Academy of Engineering, Pune. 